\title{
Facilitating Innovations in a Mature Industry-Learnings from the Skane Food Innovation Network
}

\author{
Håkan Jönsson'1, Hans Knutsson ${ }^{1}$ and Carl-Otto Frykfors² \\ ${ }^{1}$ Lund University, \\ ${ }^{2}$ Linköping University \\ Sweden
}

\section{Introduction}

The food industry is today one of the most globalized industries and subjected to growing strains. Globalization and the shift towards innovation-driven knowledge-based competitiveness between firms and regions have rendered traditional national and regional policies and concerted efforts for enhancing industrial economy and prosperity less effective. Baldwin (2006) refers to globalization as "the great unbundling". It is not just a matter of slicing up of value chains and relocating various stages of production to more comparably advantageous regions. Innovation and intrinsic knowledge creation are important parts of the renewal of national and regional policies and efforts to compete internationally.

The food industry, though, is a mature industry. Such tend to be regarded less innovative than emerging Science \& Technology-based industries. A possible reason is that they tend to be governed by social and technological regimes (Winter, 1983) related to experience and tacit knowledge built up during the long history of the sector. The food industry is not only mature, but is further characterized by complex and long value chains - shaped and formed over time.

This chapter was written from a regional perspective. In the region of Skane, located in the south of Sweden, a strong food industry has developed over centuries. The potential of Skane as a food region has been acknowledged and supported by changes in the national Swedish R\&D and industrial growth policies. The concept of sectorial innovation system and a triple helix approach is now used for enhancing the knowledge-based transition in the Swedish system (Frykfors \& Klofsten, 2011).

The major challenge in Skane was that the different actors in the food industry had different ultimate goals. Another challenge was that no single actor owned the overall strategic problem of enhancing the innovative dynamic capabilities (Teece 2007) of the local food industry forming an innovative cluster. It was necessary to reach an agreement about how to govern this joint strategic problem.

The Skane Food Innovation Network (SFIN) was established at the time of Sweden joining the European Community. As the international competition grew more apparent to companies in the Skane region, companies, universities and public authorities saw the need 
to establish a model for facilitating innovations in the food sector and to create a joint ownership of strategic questions. Since 1994, SFIN is gradually shaping the concept of innovation community. It creates dedicated sub-communities for specific areas and the innovative capability in this mature industry is gradually evolving.

This chapter describes and analyses the policy-making impact on the transition of a locally mature food industry of the Swedish province Skane into an innovative and ever more competitive international food region. The theoretical frame of reference is based upon the concept of social and technological regimes. These regimes, as will be shown, differed between major stakeholders in the region. This called for bridging activities. Several of these activities have been orchestrated by Skane Food Innovation Network (SFIN) and have helped forming new cognitive maps, in turn helping new innovation communities to form and navigate in new market spaces (Frykfors \& Jönsson, 2010).

The aim of this chapter, thus, is to present and discuss the learnings of the development of the Skane Food Innovation Network. This relates directly to the ongoing discussion about how stakeholders, both private and public, may facilitate the development of a regional innovation system.

\section{Background}

\subsection{The Skane food industry}

Skane is located in Scandinavia, in the south of Sweden and has approximately 1.2 million inhabitants. It is the center of Sweden's food industry. The region has a high density in foodrelated activities: within the 11000 square kilometers, all sectors of the food business area are found, covering the total chain from farm to fork. Primary production, the food processing industry, packaging, production machinery, distribution, warehousing and quality control can be found in the cluster. Competence in product and process development, both in industry and academia, is abundant and the marketing and R\&D functions of large companies are well developed. Retailing and food distribution companies are also present in the cluster (Lagnevik 2006).

In 2007, the industries forming the core of the Skane food industry employed approximately 25,000 people (Henning et al 2010). Definitions of the boundaries of the food industry, which companies should be included etc, are debated. While discussing the dimensions of the food industry, it has been argued that it not only includes the traditional areas of the food industry, but also industries and disciplines that have a strong link to or act in symbiosis with the food industry (Oresund food 2011:40). If the Skane food industry is broadly defined, including related businesses, an employment at about 100,000 people can be accounted for. This is high in relation to the population in the region (Wastenson et al, 1999). Moreover, Skane accounted for about 21 per cent of the total number of employees in the Swedish food sector's core industries. As Skane has about 12 per cent of the total number of economically active individuals in Sweden, this indicates a strong regional position of the food industry (Henning et al 2010).

\subsection{A changing foodscape}

During most part of the $20^{\text {th }}$ century, the Swedish food market was protected from international competition. The idea of national self-subsistence guided Swedish food policy. International competitiveness was not a major issue, since surplus production was limited. 
During the last decades though, the Swedish food industry has been rapidly changing from a sheltered national industry into an industry exposed to strong international competition. This has occurred gradually in three steps (Lagnevik 2006).

In 1986 the Swedish government declared that the food sector gradually should be exposed to international competition. This induced a change in the Swedish agricultural sector and many Swedish agricultural companies began to adapt to the new working conditions. The second step and a major change in the competitive situation occurred when Sweden joined the European Community on January 1st, 1995. By the entry, trade barriers for finished food products were completely removed. The third step occurred on May 1st, 2004, as the new member states joined the European Community. The Swedish food industry and agriculture is now exposed to fierce international competition. The closest neighbor states, e.g. Lithuania and Poland, produce agricultural bulk products at a cost that cannot be met by Swedish farms and agricultural companies. In addition, the food industry has experienced revolutions in the IT and the Biotech sectors. These technological revolutions have radically changed the working environment for food companies and increased consumer interest for organic and local food, food safety and healthy eating. All in all, this means that the whole context in the food sector has changed dramatically the last 25 years.

It is not only the competitive situation that has changed, but also how the consumers view food quality and food safety. A term developed to capture the multidimensional aspects of food, trying to give equal value to the material, social and mental aspects of food is "foodscape". The term has been used by, among others, Rick Dolphijn (2005) and Pauline Adema (2009). Building on Arjun Appadurai's (1990) influential use of different "scapes" in order to understand the processes of deterritorialization in a global world economy, we use the term 'foodscape' to try to capture the complex intertwining of people, food products, places, emotions etc. that happens in food-related situations, resulting in communal identities as well as economic, physical and social structures linked to food. This broader view on the changing conditions for the food actors is necessary in order to understand the context within which the activities of SFIN have taken place.

\subsection{The triple helix setting}

The companies in the Skane food industry are a mixture of larger national and multinational companies (such as IKEA Food services, Nestle, Findus and Atria), and SMEs, from specialized food manufacturers to small innovative research-based companies, such as Oatly. Food-related education and research is to be found at all four universities in the region, especially at Lund University (Scandinavia's largest establishment for higher education and research with over 40,000 students, founded in 1666), but also at the Swedish University of Agricultural Science, Alnarp, at the Malmö University, and at Kristianstad University College. Research in the region covers all kinds of scientific knowledge in the food chain from farming to consumer studies as well as scientific knowledge in industries related to and supporting the food chain. The Skane region also has a strong position in research and development in the companies of the food branch. Many Swedish companies have located their R\&D centers in this region, as have packaging, processing and distribution plants.). Among the food related industries, a special note should be made about the packaging industry as it represents a large sector in the region with internationally successful actors such as Tetra Pak. 
State, regional and municipal authorities support development in the food industry. In particular, the Region of Skane invests actively in the development of food-related initiatives and pursues a vision of becoming the food center of northern Europe in 2025. The state-governed county council supports local companies and initiatives consciously and forcefully.

\subsection{Features of the Swedish innovation system and innovation \& research policies}

The arena for the Swedish food industry has changed quickly and radically in just a few years. Skane, being the center of Sweden's food industry and closest to the international market, has faced an urgent need for increasing the innovative capabilities of the food industry. A brief look at the Swedish innovation policy is needed in order to describe the framework in which SFIN operates.

Understanding the rationalities of the current Swedish use of the triple helix approach requires recognition of the main structure of the Swedish economy. It reveals several distinctive features grounded in la longue durée of niche management, e.g., industrial specialization and creative use of innovative technology procurement. This has orchestrated the main features of the innovation and research policy system and its growth model for industrial development and prosperity (Freeman, 1987, Lundvall, 1992).

The concept of "development pairs" (Fridlund, 1999) describes the long-term development cooperation and close partner relationship formed between specific state client and private firms in order to exploit and develop new technology. Such relationships often played the role of driving force and a catalyst for growth of industrial development blocks (Dahmén, 1987), which later matured into defined innovation system or what Carlsson \& Stankiewicz (1995) called "technology systems". The evolution of the Swedish innovation system offers a number of examples of niche management, e.g the state power authority which historically enjoyed great freedom from political interventions and the Swedish telecom industry, and different key companies or group of key firms (Fridlund, 1999, Laestadius \& Berggren, 2000).

However, the application of development pairs has exposed some negative structural features of the concept. The most striking feature is the bifocal policy structure that is split between two subsystems - one that supports innovation and business development, and another for academic education and research. Another shortcoming in the approach is a diminutive structure of intermediaries and research institutes. A third characteristic feature is that the regional governance level is by-passed and weakened (Pierre \& Peters, 2005). The regional politico-administrative level has primarily been pre-occupied with financial support and the governance of common healthcare and communication infrastructure, while policies for research, technology and innovation (RTI) always have been a state affair. As Sweden became member of the EU in 1995, the country faced new regulations for compliance with EG legislation of procurement and trade. As a result, development pairs being the significant part of the Swedish innovation system were no longer viable. This called for a change in national innovation and research policies.

\subsection{The dawn of the Skane model of food innovation}

Influenced by the EU, the regional level in Sweden has to be more influential in issues of innovation and development policies. The shift in command, underlined by ongoing globalization of markets and of growing multinational companies, has made national innovation and growth policies less effective and more difficult to manage solely from a 
national level. In 2003, VINNOVA, the state agency for innovation and systems-oriented research, launched a regionally oriented program for research, technology and deployment/demonstration (RTD) in line with this shift. The program is based on the concept of sectoral innovation systems and the triple helix approach. The aim is to promote upgrading and renewal of local innovation and R\&D capabilities and skill building in certain important growth areas with strong regional profiles. The focus on enhancing the strength of regional constituents and supporting structures of the sector innovation system involving regional authorities has materialized in the Winn-Growth program. This program, though, calls for the development of new types of governance and practices.

One initiative within the Winn-Growth program was granted to the Skane Food Innovation Network, an innovation intermediary, a regional "facilitator" composed of companies, universities and regional authorities. The idea was to increase the return on investment and added value in the regional food industry by strategically enhancing the R\&D and innovation capacity in the food sector. A previous innovation strategy for the food sector of Skane, based on increasing internationalization and more knowledge-driven innovations, had been outlined prior to the Winn-Growth program. This had been done together with the establishment of an academic functional food research program (Nilsson 2008). Each of the regional Winn-Growth programs suggested by Vinnova run for a 10 -year period and are subdivided in approximately 3-year stages.

\section{The Skane food innovation network}

The changing competitive conditions that occurred during the 1990's had spurred thoughts among leading industrialists, in the regional government and among researchers that measures were needed to be taken if the food industry in the region should stay competitive. In 1994, the three parties consequently created a joint network organization, Triple Helix style, and named it 'The Skane Food Innovation Network'. The objective was to facilitate the exchange of research and development between universities and the food industry. In the organization, leading actors from the region did investigations and started joint actions in areas related to competence and competitiveness. The insight that major changes were ahead made leading actors work hard together to improve the future for the food industry. In this context, it is worth noting that the original initiative came from the food industry. This has created a triple helix organization in which the industry has had a leading role for more than one decade (Asheim \& Coenen 2005, Coenen 2006). From the outset, it was decided that the network CEO should have an industrial background and that the chairman of the board should be the County Governor.

The urgent need for a transition away from traditional bulk production was the major incentive for creating the organization. New knowledge and collaborations with other actors were needed in order to increase the production of specialized and highly processed products. This made some of the major players in the food industry dedicated to the organization. At the time, functional foods and convenience foods seemed to have a very promising future. Both segments demanded academic research and, although to a lesser extent, regional collaboration.

The Skane Food Innovation Network was organized as a flexible network organization, with a small, operative executive board. Through the co-operation over the years, it came to be seen as a constructive force in the regional development from both the industry and the regional authorities. In spite of the small size of the organization, when competing for the 
"Winn-Growth programme" it was seen as logical that SFIN should represent the joint innovation efforts in the region.

\subsection{From project management to innovation communities}

The Winn-Growth program multiplied SFIN's resources in a single blow. As any organization experiencing sudden growth, measures needed to be taken in order to fulfill the new goals. Over the years, continuous reconsiderations have been made. These can be divided into four phases: the starting phase, the foresight phase, the governance phase, and the community phase. The different phases were all induced by discussions about strategic issues and are therefore described in some detail. The story is based on interviews with key actors, both during the foresight process in 2006-2007 (Jönsson \& Sarv 2008) and on followup interviews in 2009-2010. Two of the authors (Jönsson and Knutsson) became members of the management group in 2009. The material is thus complemented by inside information, in an anthropological tradition described as participant observation (Davies 2008).

\section{Phase 1 - Making things start}

The SFIN Winn-Growth initiative's point of departure, outlined by professor Magnus Lagnevik at Lund International Food Studies, was that many innovations are born at interfaces. The primary aim was therefore to encourage interaction at interfaces between different areas of scientific knowledge, between different technologies, between academic research and commercial enterprises and between private and public organizations. Knowledge integration (Grant, 1996) between different knowledge areas should produce new products, services and concepts. The Triple Helix dimension was the second cornerstone of the SFIN organization, reflected in the board already from the start, with the county governor as chairman and representatives from the food business and academia in the board and management group.

In order to get things started quickly, without having to start by building a central organization, the vast majority of the funding was canalized through existing organizations. Four key development areas were defined; Functional foods, International Marketing, Food Service, and Innovation. The former three were canalized through The Functional Food research centre, Lund International Food studies and Food Centre Lund, all academic research centers within Lund University. The latter was assigned to Ideon Agro Food, a foundation working mainly on strengthening the links between academia and business, aiming to support innovation projects and technological development in the food industry. The key development area during the first years was Functional Foods. The area was at the time believed to have an enormous growth potential, and the need for knowledge integration between all sides of the triple helix was obvious. On the research side, nutrition, medicine, food technology, food engineering, marketing and consumer behavior were all relevant but shared neither traditions nor agendas. Food companies, food ingredient companies and packaging companies could join from the corporate side, all with a more congruent agenda. The county government, responsible for the healthcare in the region, could enter the cooperation with a lot of knowledge, but also as a major receiver and user of the innovation results.

During the first three-year period, the program was primarily engaged in stimulating the innovation system by providing new competence and deepening knowledge about the needs, prerequisites and opportunities for renewal of the food industry. Several PhD projects were initiated, primarily in the functional foods and marketing areas. The research 
projects were quite successful, as were many of the smaller innovation projects. Yet still, doubts were raised when the first three years of the program was about to be concluded.

Within the literature on clusters and cluster management, questions regarding the governance of clusters emerge (Nilsson 2008). Is it at all possible to govern a cluster, based upon intricate networks of actors, imprinted with different ways of thinking and acting? The Skane food innovation network had expectations from both its members and its funders (primarily Vinnova) to govern the innovation efforts in the Skane food industry. These expectations created an urgent need for rethinking the initial approach, based on the idea of outsourcing dedicated projects to organizations beyond the control of the SFIN organization. There were good reasons for the reconsideration: there was a wish to keep administration at a minimum and a clear need to position SFIN distinctly in relation to other facilitating organizations active in the industry. After the first three years, the problem of organizing the innovation efforts became obvious. It was probably efficient to get research and R\&D project conducted by delegating them to specialized organizations and institutions. However, with a central organization without the resources to fully coordinate the outcomes of the separate projects, the Winn-Growth project appeared to be any other funder of research and innovation projects, with the strategic challenge and direction being left out. Another problem was the decreasing engagement from the business. The first years saw massive investment in research, which takes time to deliver useful results, especially since many of them were four-year $\mathrm{PhD}$ projects. The fact that the hype around functional foods cooled down these years made the connections between business and academia weaker. Concerns were raised about the dedication of resources from the industry. A longterm strategic discussion was initiated, both from Vinnova and from SFIN. What was the role of SFIN, really?

\section{Phase 2 - Foresight as pit stop}

Each of the regional Winn-Growth programs granted by VINNOVA ran for a 10-year period and was subdivided in approximately 3-year stages. Prior to each stage, an update of the program content was undertaken, involving the reconsideration of a relevant set of regional stakeholders and measures. In the intersection between the first and second stage of the SFIN program, a foresight process was suggested in order to navigate in a changing "foodscape" since both key stakeholders and markets were in transition. The foresight process should also strengthen the Innovation Network's governance of the "regional food cluster" of the sectoral innovation system, in accordance with the experiences mentioned above. The foresight exercise was part of an EU-funded four-party foresight development project titled Foresight Lab (www.innovating-regions.org). The main goal for the "systemic" foresight was not to do a full-scale foresight, but to strengthen the innovation community in order to make the food cluster more competitive when future opportunities emerged.

The foresight identified three major challenges for the governance of the food cluster. The first and foremost was to make actors in the triple helix-perspective more profoundly committed to the idea of building a regional-based food innovation community. The regional perspective was not self-evident to many of the actors - they were regularly working in organizations where either a larger geographical area (national and/or global for the major companies) or a smaller area (sub-regional or local for the micro businesses) was being in focus for the business strategy and development activities.

The second was the heterogeneous character of the food innovation system. There were many small businesses throughout the value chain, from farmers over food producers to 
grocery stores, restaurants and public eating-places (retail and wholesale being somewhat more centralized). Some actors did not feel connected to other levels in the food chain, while others felt a need to establish collaborations, but uncomfortable with the process. At this point in the process it became obvious that the Swedish food system (as many other mature industrial sectors) had established strong regimes on each level of the food chain, with little or no understanding of the actors on other levels.

The third challenge for the foresight activities rose from the different social and technological regimes of the actors. This called for bridge-building activities that could translate and transform the disparate cognitive maps in order to build an innovation community that could navigate together in the new market. All actors were imprinted with values emergent from a time when the Swedish food system was based on national selfsubsistence, with limited market competition. This was a major impediment for crosssectoral innovation, since the new situation demanded new ways of collaboration and consistent interpretation of the foodscape. Although difficult, the timing was right. Since the regimes already were in transition, all actors were aware of the need for new working methods and collaborations.

The foresight confirmed several strengths of the Skane food industry, such as the presence of all vital parts of the supply chain, a strong, academic research tradition, and a well developed, common sense approach for food pleasure at the regional community levels. But findings also pointed especially to some weaknesses and threats in terms of "gaps". Hence, different needs and measures for strengthening the "bridges" across knowledge areas, long and short term plans and actions, big and small businesses, parties in the supply chain, research and business and among different levels of the innovation system (Jönsson \& Sarv 2008).

Four potential sub-communities were identified from the mapping as being of particular interest to SFIN. In line with the systemic idea of developing the communities from a learning partition perspective, with knowledge and governance partition support, four systemic meetings were launched, with open invitations to all relevant actors. After the meetings, an ex post analysis of the foresight exercise and its outcomes was made. The focus was upon governance and how the organization could be developed in order to take a strategic leadership of a heterogeneous food innovation and production system. Governance-related services were hereby identified as particularly interesting services in the upcoming foresight work. Consequently, four focus areas were proposed: 1) launch new services (such as systemic meetings for sub communities in the food innovation system and dedicated knowledge partition services for hot areas), 2) develop innovation community and foresight governance, 3) increase communication and bridge building by continuously publish innovation community progress on an interactive basis, 4) investigate in innovation system research (research that not only formulates bases for food innovations, but also contributes to the development of the innovation system as a whole).

For all focus areas, specific activities were proposed. The analysis finally concluded that the different suggestions reinforced one another, and should therefore be developed concurrently, on an experimental and learning-oriented basis. Both "direct innovations" and cross discipline research projects were noted in the results in addition to the new knowledge and experiences regarding foresight work. In particular, the linking of the food innovation system with the health innovation system and the improved integration of retailers into the food innovation network was very promising (Jönsson \& Sarv 2008). The foresight became a 
catalyst in the development process that Skane Food Innovation Network initiated in 2006. In 2010, most of the proposals of the Foresight's concluding report have been implemented.

\section{Phase 3 - Establishing governance and credibility}

Parallel and in continuous dialogue with the foresight process, organizational changes within SFIN took place. A new CEO, Lotta Törner, was recruited in 2006, and a reorganization of the board with the new county governor as chairman took place. In the dialogue with the major players from the business side, it was obvious that, from their perspective, there had been too much emphasis on long term academic research. Given the question what SFIN as an organization could do, the answer was primarily to enhance the attractiveness of the food business. For a long time, the industry had faced problems with recruiting highly educated younger people. A stronger focus on supporting the latter phases of the innovation process, to get new innovative products, concepts and services on the market, was further proposed.

The period led to a greater focus on meeting places. A number of meeting places were developed. Here, representatives of various interests and competencies could exchange and discuss ideas and develop creative solutions and business ideas. The existing meeting places were upgraded. The annual "Network day" were turned into a meeting place for most of the food sector in the region by inviting internationally renowned speakers and awarding research prizes and scholarships of a combined value of almost 100000 euros in collaboration with a large foundation in the food and health area.

Furthermore, dedicated sub networks were established. A network of CEO's was formed, in which the most prominent CEOs of the food business now meet on a regular basis to exchange ideas and to discuss present and future challenges. This was a direct result of a foresight activity, where it was identified that the CEO's needed a special network in order to be committed to development projects outside their own companies. A Research Network was created as a meeting place for interdisciplinary contacts for food scientists from all faculties and universities in the region. The network is organizing seminars and workshops on "hot areas". A Retailer Network was organized in order to get the retailers more involved in the Innovation community. This was arranged as a part of a platform for innovative market places in order to integrate the retail side in the food innovation community and to promote innovative market solutions. The platform Future Meal Service, focusing on meals in the public sector was another initiative during this period. An Entrepreneur Council, where entrepreneurs can present their ideas and get professional advice and seed money in order to make their business ideas successful was further established.

The constant need for upgrading the creative capability of the innovation system was recognised as an important factor for the future, not least since the Winn-Growth program ends in 2013. The establishment of foresight as a continuous process was decided as a strategy in this work. Systemic meetings are being used whenever interesting projects materialize. A new arena for developing contacts between the packaging industry and the food industry in order to develop "Innovative food in innovative packages" is one example of the results generated from the systemic meetings. As part of the foresight process, there has been an increased focus on international bench learning.

A lot of focus was given to the Student Recruitment Program, reflecting the business representatives wish for activities dedicated at enhancing the attractiveness for the food industry among younger people. A starting point was to establish an Advisory Board with 
students. Ten students from different educational programs gathered together with the assignment to give the Network and the individual companies valuable input on how the best brains can be recruited to the food sector in the future. In order to improve contacts between companies and educational programs, the students on the Advisory Board arranged field trips to companies and lectures by CEOs at universities and colleges. In collaboration with Skane Food Innovation Network's communication manager they have designed a web-based "career" site. The advisory board's activity led to the establishment of a joint trainee program, where five companies assigned in total eight trainees for a period of sixteen months. The trainee program offered a mix of company-based work and joint activities. The establishment of a joint trainee program showed the high degree of credibility as a neutral arena as the SFIN had established from the companies perspective.

Finally, attempts were made to use diversity as a tool for adding new perspectives to the innovation climate. Traditionally, the food industry has been dominated by male, ethnic Swedes. This means that both women, and the fast growing immigrant population, have been under-represented in key positions in the food industry, even though there is a lot of competence and entrepreneurship in both groups. The research project Power over Food, that started in 2009 is addressing the question "How can better knowledge of gender and equal opportunity issues in organizations and companies create more and better food innovations?" There are suspicions that many capable female researchers and entrepreneurs terminate their careers in the food field. That implies a risk that many ideas for potential innovations come to nothing. The project wants to find out if this loss is related to attitudes about gender and equal opportunity, and then come up with possible changes that can encourage more people to remain in the business. The development of "Etnos", a project devoted to producers of ethnic foods in Malmö funded by the Skane Food Innovation Network and the Skane County Administrative Board considerably increased the diversity in the program. This ethnic network consists of food entrepreneurs with background in other countries than Sweden.

\section{Phase 4 - Expanding the innovation community}

After reassuring commitment from the main initiators of the network, SFIN in 2009 took several steps in order to strengthen the governing capacity and expanding the innovation community. The management group was expanded and re-organized into strategic areas. These were "Strategy \& Cooperation", "Jobs \& Careers", "Tomorrow's Meal Services", "Innovation \& Entrepreneurship", and "Taste of Skane" (formed in 2010).

The distinct areas of responsibility demand a deliberate cross-fertilization and commitment from the different areas. The heterogeneous food innovation system requires "multilingual" skills. This was explicitly searched for by the CEO when recruiting the members of a new, larger management group. Apart from having knowledge and authority in the various areas, the members were constantly asked to make sure that the integration and crossfertilization between the different areas was functioning.

Strategy $\mathcal{E}$ Cooperation was dealing with the overarching questions for the whole SFIN network. Jobs $\mathcal{E}$ Careers were targeted at the attractiveness of the food business, with the advisory board, trainee program and establishing connections between gifted students at universities and university colleges and the food industry. Tomorrow's Meal Services is focusing on meals in the public sector. Special emphasis is given to education and innovative purchasing procedures. The existing procedures don't promote new meal 
solutions or food products and the average education level in this part of the industry doesn't suffice in the contacts with private suppliers and competitors. In this platform the collaboration between all parts of the triple helix is most prominent, based on the idea of getting better meal solutions. Food for elderly people and hospital meals are top priorities within the area. Innovation $\mathcal{E}$ Entrepreneurship is the area in which the development and marketing of new products and processes are supported, either by dedicated small funding or by competent coaching from experienced business people connected to SFIN.

The initiative for SFIN had come from the traditional large-scale food industry, with the regional authorities and academia as main supporters. However, the changes in the foodscape, especially at the demand side of the food system, had created new opportunities and challenges for the food sector. While the food industry faced decreasing margins and fierce competition, the gastronomic side of the food business started to boom during the 1990s. From being a nation in the culinary outskirt, Sweden and its neighbouring Scandinavian nations had a rapid development in the fine dining sector. Swedish chefs started to win prestigious culinary awards and the restaurants with Michelin stars had an impressive development. Sourdough bakeries made people lining up for buying crispy bread at prices that must have seemed like a wet dream for the large bakeries delivering bread to discount stores and super markets. The media's infotainment programs made new generations discover the pleasures of cooking, starting to demand high-class products, new vegetables and spices, and rare cuts of meat from the local supermarket. And the on-going debate on food safety and food quality led to a growing appreciation for food experiences based on authentic, traditional and local values. Small-scale food manufacturers got a revival, often integrating their production with culinary tourism.

Restaurants and small-scale food manufacturers were already connected in networks, based on mutual commercial interests. But the connections with the large-scale food and retail systems were poor. The region hosted a separate development organisation for culinary tourism, restaurants and food manufacturers. However, a mutual interest had been starting to grow between the separated food domains. The food industry saw that large numbers of consumers were willing to pay considerably higher prices for authentic high-class taste experiences, an added value that not even the hi-tech products of convenience and functional foods had been able to accomplish. The small food manufacturers had limited access to necessary retail and distribution channels in order to expand and/or make their sales profitable. Here they saw a potential in collaborating with the larger players.

In 2010, the regional authorities decided to let their separate development organisation for culinary tourism and small-scale food manufacturers be handed over to SFIN. The former platform Innovative Market Places was integrated as a part of the platform Taste of Skane, directed at the concrete local development of on one side the small-scale food production and distribution, and on the other side the local culinary tourism. From now on, the whole food business, from fine dining to bulk production, was hosted by one single organisation in order to facilitate cross-fertilization between small-scale and large-scale food activities.

If the different regimes of the food industry, the academia and the regional authorities had been somewhat difficult to bridge, this was nothing compared to the separate traditions of food service and restaurants, and small-scale and large-scale food producers. Some of the differences were hidden, but some were clearly outspoken. Many of the small food manufacturers had started their business in direct opposition to the food industry's way of growing and processing food. Although in essence being committed to collaboration, the 
mistrust is not easy to overcome. But some development projects have been mutually attractive. A successful pilot project has concerned the development of a joint retail brand for local food. The retailers' network had already been discussing the need for an easy way for the consumer to buy local premium food in ordinary supermarkets. Despite consumers' positive attitudes, local food (i.e. local provenance) had not been commonly promoted in the Swedish supermarkets. Local food with a strong local profile had mainly reached the consumers through alternative channels, such as the Farmers' Market (Ekelund \& Fernqvist 2007). Since Swedish food retailing is highly concentrated to four actors, accounting for 76 per cent of all food retail sales (Market Magasin, 2008), it seemed necessary for food products promoted as local, to be sold through the supermarkets in order to grow beyond being pure niche products. By relocating the food products in the store, and developing information material and a joint brand, the small-scale food products are now easy to locate within the stores of the participating retailers. The brand "Taste of Skane - carefully selected local food" remedies the producers' concern that their products were insufficiently exposed in ordinary supermarkets. So was their concern about low profitability, since the retailers agreed upon having somewhat lower margins on the selected products. It shows the potential of collaboration if there is both a short-term gain for the users, and a larger good (regional food) that could engage the actors apart from strict business considerations.

A parallel development is to be found in the SFIN "Chefs' network". It turned out that some of the more prominent chefs in the region were interested to contribute with the experience and knowledge to the public sector. Since this particular part of the food industry, municipal and county foodservices, is a low-status, low-wage part of an already meagre sector, the initiative was welcomed. One of the most renowned chefs in the region started up a small chefs' network with only two chefs from the public sector and two from the private sector. These four people had the assignment of identifying urgent development areas where the cross-fertilization between sectors could be meaningful. A new dimension was introduced to the SFIN agenda, industry development hand in hand with corporate social responsibility. Gradually, the chefs' network has turned into a "meal network", where a much wider array of competencies and backgrounds now join forces in order to revitalise the entire meal situations in various areas within the public sector. It is behavioural consultants, architects, chefs, nutritionists, etc. Different projects have up until today covered elderly care, education in food and meal knowledge, health care and disabled people. They all share the characteristics of not being commercially "hot" and the innovative solutions are all needed in the entire sector. The pilot projects are high-risk and designed with replication criteria and business potential, in case the projects turn out well. The common denominator for the meal network is to redefine the meal situations for those who do not choose for themselves what and when to eat. Although the agenda is clear, the bridging of different areas is not easy. Being public operations, these are all relying on political decisions. The public foodservice has been neglected for a long time and is devoid of any national, regional and even local co-ordination and suffers from poor funding and low status. However, the regime of public foodservice is increasingly scrutinized, media interest grows and points out the social as well as nutritional importance of public meals. The sector has a potential to raise the bar for product and process innovation within the entire Swedish food industry. Thus, the natural extension of the meal network within the area of Tomorrow's Meal Services is the establishment of a politicians' network, which is currently underway. The public authorities may turn out to be the most vital part of the triple helix structure underpinning the SFIN operations - not only as a primary funding source, but also as an increasingly demanding end-user in the Swedish food industry. 
Both the retailers' network and the meal network initiate and run risky pilot projects with a business potential for involved entrepreneurs and other incumbents. Pilot projects are carefully selected and consciously and strategically granted. In this way, relatively small initial pilot project fundings may reproduce themselves in the industry, on sound commercial conditions.

\section{Summary on findings}

The story of Skane Food Innovation Network and its efforts in stimulating innovation in the regional food industry boils down to four main topics: the organization has been developed, managerial crossroads have been designed, stakeholder interests have been aligned, and SFIN has found a viable modus operandi in its risky pilot projects with reproduction and diffusion potential.

\subsection{Organizational development}

The SFIN organization has evolved, in seven years, from strict and arms-length $R \& D$ funding into a multilevel and multidisciplinary innovation community.

An important insight was the need for dedicated sub-communities, i.e. "focal networks", with hands-on activities, in turn co-ordinated in the overarching food innovation network. This combination creates opportunities for direct innovation in the sub-communities as well as creating a breeding ground for cross-fertilization between the sub-communities.

\subsection{Managerial crossroads}

The SFIN story reveals how the Triple Helix approach has been gradually operationalized through board representation and a "multilingual" management group. The role of the management team has been sharpened and requires both depth and breadth from the area managers. The managers need to be skilled intermediaries with an ability to identify and translate differences across differing regimes. Cultural differences between large and small, public and private, primary production and retailing, etc, influence community building activities. At the same time, cultural impediments may well hold the potential innovation (Jönsson, 2008).

\subsection{Alignment of stakeholder interests}

SFIN has gone through a drastic change from being preoccupied with the funding of R\&D projects without any joint strategy, into engaging in cross-sectorial collaborations. A recent study of the Skane food industry concluded that SFIN have had a significant impact on reducing the fragmentation in the industry (Henning et al, 2010). Gradually, joint arenas become legitimate and the strategic and long-term nature of the SFIN operations spread among different actors. This makes it less threatening to engage in open innovation-kind of collaboration, as long as it resides under the "neutral" SFIN label.

\subsection{Emergence of a modus operandi}

In seven years, SFIN has turned into a network of cross-functional networks defining and funding risky pilot projects, commercially viable and with diffusion potential. The diffusion process is backed up by support activities such as marketing and communication, but the business potential is for the entrepreneurs to realize. In this way, funding exploits the 
incentives of entrepreneurs, at the same time receiving a "reality-check" from the level of interest expressed by entrepreneurs in the first place. Furthermore, small funding may be leveraged into, at best, increased economic activity and societal improvement.

\section{Discussion and outlook}

The Skane Food Innovation Network operates on many fronts to boost the impact of innovation in the food industry. The Network also tries to create the conditions for innovation by enhancing the attractiveness of the food business. It has been a tricky road, with successful paths as well as some dead ends. Although promising, the work of SFIN is only at the beginning of the transition processes in the Skane food sector. The changing foodscape, with completely new situations for both farmers, industries and retailers, calls upon new and innovative solutions. Most of the mature industries tend to have the same problems, such as well-established regimes, created in very different markets. These regimes are de facto impediments to innovation. In this section, we will discuss the learnings of the work of SFIN with facilitating innovations in a mature industry, focusing on the use of a multilevel triple helix approach, the importance of analyzing and bridging regimes and the importance of an end user perspective as a guiding principle.

\subsection{The multilevel triple helix network approach}

The food innovation system is heterogeneous, with a mix of large national and inter-nordic producers and retailers and many small local businesses all through the value chains. It spans from farmers over food producers to grocery stores, restaurants and public eatingplaces. This characteristic was initially a major problem when trying to build an overarching innovation community and common ground for concerted efforts. Some actors did not feel connected to other levels of a presumptive cluster in the food chain, while others felt a need to establish collaborations but felt insecure about the process. This mirrored the fact that the Swedish food system, like many other mature industrial sectors, had established strong regimes on each level of the food producer-consumer chains, with little or no understanding of the actors on other levels. All actors were imprinted with values emergent from a time when the Swedish food system was based on national self-subsistence and strong public regulations, resulting in limited market competition (Beckemann 2011). This was a major impediment for cross-sectoral innovation, since the new situation demanded new ways of collaboration.

The triple helix approach is concerned with joint efforts and coordination, in our case between universities, business firms, local production units of large multinational companies and regional authorities. Different stakeholders have their individual rationales and logic. In order to be successful, the triple helix approach should rest on mutual trust and goal congruence between incumbents. Bridging regimes is like an evolution, an emerging understanding of the common good of a change of strategy and behavior.

\subsection{The importance of analysing and bridging regimes}

The fact that processes underlying innovation and industrial and economic transformation are governed by social and technological regimes have been acknowledged by, among others, Cooke, (2005), Geels, (2008), Bergek et al, (2007), Klein Wollthuis et al, (2005) and Malerba and Orsenigo, (1997). Winter (1983) defines regimes in a sector as a specific set of 
not only regulative institutions and norms but regimes also regulate codified formal as well as tacit informal habits and routines related to common collective and individual practices and beliefs. These practices and beliefs shape and coordinate actions between various groups, individuals, and organizations in the sector. The notion that technological regimes and their production of knowledge are shaped by historical and cultural factors have, from a different starting point, been repeatedly argued in the tradition of cultural analysis, which have become used more often in both product development and marketing in the latest decades (Pink, 2005. Sunderland \& Denny, 2005. Kedia \& Van Willigen, 2005). The tradition of cultural analysis further stresses that technological systems do not function independently from the human actors within the system. The actors are seen as embedded in social groups with cultural requisites, such as traditions, norms and beliefs (Law, 1999).

Breschi and Malerba (1997) concluded in their studies of sector characteristics of national innovation systems that technological regimes are defined by the level and type of opportunity and appropriate condition to innovate. This is bonded to the history, nature and the cumulativeness of knowledge as well as to the means of communication and transmission of knowledge within the sectoral systems of production. Following Levinthal (1991) and Scott (1995) regimes have three dimensions: i) cognitive rules, related to belief systems, ii) normative rules expressed in missions, goals, and identity, and iii) strategies and strategic orientations towards the surrounding external socio- technical and politicoeconomic environment. Regimes are closely related to the concept of institution. An institution could be defined as "patterns of routinized behaviour" (Hodgson, 1988) and may be analysed on a number of different levels.

In the networks of SFIN, it is a number of sub-systems who engage and challenge current regimes. The result is ideas, tested in "risky pilot projects" with diffusion and profitability potential. The networks may be understood as "liquid environments", where different knowledge, experience and values meet (Johnson, 2010). Such liquid environments define the so-called "adjacent possible" (ibid.). This means that the configuration of single networks and the links between the individual networks constitute the limits to what the network may produce. i.e., configurations are imperative. The regimes are influenced by the experience, thoughts and ideas, values and objectives of each and every individual within the different networks. SFIN organizes the network of networks and initiate pilot projects. On this level, cognitive rules are tested and different belief-systems are bridged in the work of individuals.

Leaving the individuals' level, the next level may be approached from a business angle. Business firms are normally run with a profit incentive. Innovations aim at creating new or better value to customers, leading to sales and profits. Following Christensen (1997), the average company inherently faces difficulties innovating a thriving business. Organizational routines and activities are shaped for efficient use of resources. Business innovation implies the change of product offerings, markets or resource use and the re-shaping of the "theory of the business" (Drucker, 1994). In terms of regimes, innovation by definition alters the business regime in one way or another, disruptively or incrementally (Christensen, ibid.). Govindarajan and Trimble (2010) are pre-occupied with "solving the execution challenge", focusing the way that an on-going business may handle challenging ideas and taking them to market. A new idea could form a spin-off initiative and be the start of an entirely new company. However, firms also need to innovate their current businesses, why it is necessary to establish a formalised co-operation between the existing business and the innovation 
initiative. What Govindarajan and Trimble (ibid.) suggest is a gradual and well-managed integration of old and new regimes in terms of both social and technological challenges. SFIN relieves the established firms from the direct disturbances of challenging ideas, working as an outside test-lab without worrying the on-going business. Still, the CEO network and the Entrepreneur Council bridge the gap between established practices and innovations developed in the pilot projects. Both social and technological regimes are bridged by way of the SFIN networks.

Different regimes that have their own specific cultures have been developed during the long history of the national food system in Sweden. By opening up arenas for individuals to meet, to identify and test new ideas, SFIN helps established firms to engage in innovation without compromising their running business. At the same time, entrepreneurs are invited to a vibrant group of people all joined in the common interest of developing the food industry by "open innovation".

\subsection{The importance of an end user perspective}

The end-user perspective is notable in the literature on open innovation (Chesbrough, 2006. von Hippel, 2005. Wallin, 2006), which stresses the importance of integrating the demand side in the study with the development of innovation systems. The action taken in the extended network all followed one of the major recommendation from the foresight process: take the end user perspective as a starting point. The user side was also used as a start for community building activities, whether it was the student recruitment program, the local food or the food for elderly activities.

Bringing the end-users helped to synchronize the agendas of the different actors in a multilevel food triple helix space and a multilevel foodscape. The end user perspective made the participating actors really feel that although they couldn't solve the problem by themselves, they all had important contributions to make. We conclude that the user side cannot be reduced to the result of the innovation system or the triple helix actors' achievements in a conventional way, since the user side interacts with every level and affects the outcomes from an early stage. The end-users have of course always been the important landing point for innovation work, the place where the success of the attempts to innovate is determined. But our point is that they may also be the best starting point, since it is the only level to which all actors of the triple helix can relate.

\subsection{A new innovation systems model}

The experience this far shows that SFIN engage a wide range of stakeholders in its different networks. Small-scale food producers, public servants, small service businesses, large retailers, politicians, entrepreneurs, large international food-related companies, researchers etc join the different networks of SFIN. Individuals meet in focal networks, form pilot projects which drive economic development in the industry from within. The former Swedish innovation system using "development pairs" in order to direct - "top-down" - the formation of an entire industry through a single company is gradually supplanted by the bottom-up network model strengthening the inherent innovative capabilities of a wide range of small and medium-sized firms, as well as larger corporations and public organizations. We suggest that the SFIN triple helix-based network form of organization holds several strengths. It is dynamic in its formation, it is resilient to temporary failure and it is cost-efficient in its selection and execution phases - it uses entrepreneurial incentives 
and helps isolating innovation initiatives from on-going business in established firms. Although it remains to be tested, this could be considered an efficient way of bridging strong regimes of a stifled and mature industry. It could be the Swedish food industry, but the mechanisms controlling the network of networks may well be transferred to other industries sharing these characteristics.

\section{Concluding remarks}

We would argue that the related work methodology of SFIN may be part of a transition from the prevalent Swedish innovation and development mode and work as a model for facilitating innovations in mature industries. The combination of an overarching innovation network responsible for issues of governance, in combination with dedicated subcommunities implementing hands-on activities and projects was a major step forward from the original SFIN organization, which was based on a traditional way or organizing innovation facilitators in Sweden. We would like to call the refined methodology a Régimebridging strategy, with a multilevel triple helix approach and an end user perspective as fundamental cornerstones.

\section{Notes on contributors}

Håkan Jönsson, associate professor in European Ethnology is researcher and lecturer at the Department of Arts And Cultural Sciences at Lund University, where he teaches at the Master of Applied Cultural Analysis program (www.maca.ac). He is also head of operations in the Skane Food Innovation Network, responsible for the area of small scale food manufacturers and culinary tourism.

Hans Knutsson is assistant professor at the School of Economics and Management, Lund University. He teaches accounting, management control, and strategy and focuses his research on public management and cluster development. He is head of operations in the Skane Food Innovation Network, running the area Foodservice of Tomorrow.

Carl-Otto Frykfors is affiliated to the Department of Management and Engineering at Linköping University and prior senior program manager at VINNOVA, The principal governmental agency for knowledge driven industrial renewal and innovation. He was further director of The Dahmén Institute in charge for evaluation of Foresight activities related to an European Foresight project between regions in Sweden, Italy, Germany and Poland.

\section{References}

Adema, P. 2009. Garlic Capital of the World: Gilroy, Garlic, and the Making of a Festive Foodscape. Jackson: University Press of Mississippi.

Appadurai, A. 1990. 'Disjuncture and Difference in the Global Cultural Economy' Public Culture 2: 1990, pp 1-24.

Asheim, B. T. \& Coenen, L 2005 Knowledge bases and regional innovation systems: Comparing Nordic Clusters in Research Policy 34 pp 1173-1190

Baldwin,R., 2006. Globalisation: the great unbundling(s). Report Prime Minster's Office, Economic Council of Finland. 
Beckemann, M. 2011. The Potential for Innovation in the Swedish Food Sector. Lund: Lund University Press (diss.)

Bergek, A., S. Jacobsson, M. Hekkert, and K. Smith. 2007. Functionality of innovation systems as a rationale for, and guide to innovation policy. In: Innovation policy, theory and practice: An International handbook, ed. R. Smits, S. Kuhlmann and S. Shapira. Cheltenham, UK: Edward Elgar.

Breschi, F., and F. Malerba. 1997. Sectoral innovation system: Technological regimes, Schumpeterian dynamics and spatial boundary. In System of innovation, technologies, institutions and organizations, ed. C. Edqvist. London: Pinter.

Carlsson, B. and Stankiewicz, R. (1995): 'On the nature, function and composition of technological systems'. In: Carlsson, B. (ed.): Technological Systems and Economic Performance: The Case of Factory Automation. Dordrecht: Kluwer Academic Publishers. pp. 21-56.

Chesbrough, H.W, 2006. in Open Innovation: Researching a new Paradigm, eds Chesbrough; Vanhwerbeke; West, Oxford University Press.

Christensen, C.M. 1997 The innovator's dilemma. When new technologies cause great firms to fail. Harvard Business School Press, Boston.

Coenen, L 2006 Faraway, so close! The changing geographies of regional innovation. CIRCLE. Lund University, Lund.

Cooke, P. 2005 Regionally asymmetric knowledge capabilities and open innovation: Exploring Globalisation 2 -A new model of industry organization. Research policy 34(8):1128-49

Davies, C.A 2008: Reflexive Ethnography. New York: Routledge

Dahmén, E. 1987. 'Development Blocks' in Industrial Economics'. Scandinavian Economic History Review.

Dolphijn, R., 2005. Foodscapes. Towards a Deleuzian Ethics of Consumption. Delft. Eburon Publishers.

Drucker, P.F. 1994, The Theory of the Business, Harvard Business Review, September, pp. 95-105.

Ekelund, L., Fernqvist, F 2007 'Organic Apple Culture in Sweden'. The European Journal of Plant Science and Biotechnology

Freeman, C. 1987 Technology Policy and Economic Performance: lesson learned from Japan. London, Printer Publisher.

Fridlund, M, 1999. Switching Relations and Trajectories: The Development Procurement of the Swedish AXE Switching Technology, in: Charles Edquist, Leif Hommen \& Lena Tsipouri, eds., Public Technology Procurement and Innovation, Economics of Science, Technology and Innovation v. 16. Norwell, Mass.: Kluwer Academic Publishers, 143-165.

Frykfors, C-O., Klofsten, M. 2011. Emergence of the Swedish Innovation System and the Support for Regional Entrepreneurship: A Socio-Economic Perspective, in Science and Technology Based Regional Entrepreneurship: Global Experience in Policy and Program Development, ed. Mian, S.A. Edward Elgar.

Frykfors, C-O, Jönsson, H; 2010 'Reframing the multilevel triple helix in a regional innovation system: a case of systemic foresight and regimes in renewal of Skåne's food industry' Technology Analysis \& Strategic Management 2010, 22, 819-829 
Geels, F. W. 2004. From sectoral systems of innovation to socio-technical system. Insights about dynamics and change from sociology and institutional theory. Research Policy 33 (6-7) pp 897-92.

Govindarajan, V., \& Trimble, C. 2010 The other side of innovation. Solving the execution challenge. Harvard Business Press, Boston.

Grant, R. M 1996, 'Toward a knowledge based theory of the firm', Strategic Management Journal, 17, Special Issue Winter, 93-109.

Henning, M, Moodysson, J, Nilsson, M 2010. Innovation and regional transformation From clusters to new combinations. Malmö: Region Skåne

Von Hippel, E 2005 Democratizing Innovation. MIT Press Chambridge

Hodgson, G. 1988 Economics and Institutions, Polity Press.

Johnson, S. 2010 Where good ideas come from. The natural history of innovation, Penguin Group, New York.

Jönsson, H 2008. The Cultural Analyst - an Innovative Intermediary?' // ETN 2/2008. Lund: Etnologiska Institutionen.

Jönsson, H \& Sarv, H 2008. On the Art of Shaping Futures. Lund, Skånes Livsmedelsakademi.

Kedia, S.; Van Willigen, J. 2005. eds. Applied Anthropology. Domains of Application. Westport, CT: Greenwood.

Klein Woolthuis, R.; Lankhuizenb, M.; Gilsing, V, 2005. A system failure framework for innovation policy design in Technovation 25 (6), pp 609-19.

Laestadius, S., Berggren, C., 2000. The embeddedness of industrial clusters : the strength of the path in the Nordic telecom system. Stockholm: Royal Institute of Technology.

Lagnevik, M 2006. 'Food innovation at interfaces: experience from the Öresund region', in Hulsink, W.; Dons, H. (Eds.) Pathways to High-Tech Valleys and Research Triangles. Wageningen: Wageningen UR Frontis Series, Volume 24

Law, J. 1999, ed. Actor Network Theory and After. Oxford, Blackwell.

Levinthal, D.A. 1991. Organizational adaption and environmental selections-interrelated processes of change. Organization Science 2: 140-45.

Lundvall, B-Å. 1992, National Innovation System : Towards a Theory of Innovation and Interactive Learing, London: Printer Publisher.

Malerba,F.; Orsenigo, L. 1997 Technological Regimes and Sectoral Patterns of Innovative Activities. Industrial and Corporate Change 6: 83-119.

Market Magasin 2008

Nilsson, M. 2008. A tale of two clusters. Sharing resources to compete. Lund: Lund Business Press.

Oresund Food. 2011 Redefining the Food sector. Copenhagen: Oresund Food

Pierre, J.; Peters, B.G. 2005. Governing Complex Societies: Trajectories and Scenarios. Basingstoke, Palgrave.

Pink, Sarah, 2005. ed. Applications of Anthropology. Professional Anthropology in the Twenty-first Century. Oxford, Berghahn Books.

Scott, W.R. 1995 Institutions and Organizations, Sage, Sunderland, P. L.; Denny, R. M., 2007. Doing Anthropology in Consumer Research. Walnut Creek: Left Coast Press.

Teece, D.J. 2007 Explicating Dynamic Capabilities: The Nature and Microfoundations of ( Sustainable) Enterprise Performance, Strategic Management Journal 28, 1319- 1350. 
Wallin, J. 2006. Business Orchestration: Strategic leadership in the Era of Digital Convergence. John Wiley \& Sons Ltd.

Wastenson, L., T. Germundsson, P. Schlyter, the Swedish Society for Anthropology and Geography, Statistics Sweden, Lund University. Department of Social and Economic Geography, National Atlas of Sweden and National Land Survey of Sweden 1999. Sveriges nationalatlas (National Atlas of Sweden). Vällingby, Gävle, National Atlas of Sweden (SNA); Publisher and distributor of maps. 
SCIENTIFIC, HEALTH

AND SOCIAL ASPECTS

OF THE FOOD

INDUSTRY

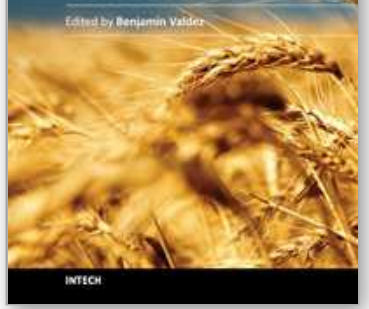

Scientific, Health and Social Aspects of the Food Industry

Edited by Dr. Benjamin Valdez

ISBN 978-953-307-916-5

Hard cover, 488 pages

Publisher InTech

Published online 01, February, 2012

Published in print edition February, 2012

This book presents the wisdom, knowledge and expertise of the food industry that ensures the supply of food to maintain the health, comfort, and wellbeing of humankind. The global food industry has the largest market: the world population of seven billion people. The book pioneers life-saving innovations and assists in the fight against world hunger and food shortages that threaten human essentials such as water and energy supply. Floods, droughts, fires, storms, climate change, global warming and greenhouse gas emissions can be devastating, altering the environment and, ultimately, the production of foods. Experts from industry and academia, as well as food producers, designers of food processing equipment, and corrosion practitioners have written special chapters for this rich compendium based on their encyclopedic knowledge and practical experience. This is a multi-authored book. The writers, who come from diverse areas of food science and technology, enrich this volume by presenting different approaches and orientations.

\section{How to reference}

In order to correctly reference this scholarly work, feel free to copy and paste the following:

Håkan Jönsson, Hans Knutsson and Carl-Otto Frykfors (2012). Facilitating Innovations in a Mature IndustryLearnings from the Skane Food Innovation Network, Scientific, Health and Social Aspects of the Food Industry, Dr. Benjamin Valdez (Ed.), ISBN: 978-953-307-916-5, InTech, Available from:

http://www.intechopen.com/books/scientific-health-and-social-aspects-of-the-food-industry/facilitatinginnovations-in-a-mature-industry-learnings-from-the-skane-food-innovation-network

\section{INTECH}

open science | open minds

\section{InTech Europe}

University Campus STeP Ri

Slavka Krautzeka 83/A

51000 Rijeka, Croatia

Phone: +385 (51) 770447

Fax: +385 (51) 686166

www.intechopen.com

\section{InTech China}

Unit 405, Office Block, Hotel Equatorial Shanghai

No.65, Yan An Road (West), Shanghai, 200040, China

中国上海市延安西路65号上海国际贵都大饭店办公楼405单元

Phone: +86-21-62489820

Fax: $+86-21-62489821$ 
(C) 2012 The Author(s). Licensee IntechOpen. This is an open access article distributed under the terms of the Creative Commons Attribution 3.0 License, which permits unrestricted use, distribution, and reproduction in any medium, provided the original work is properly cited. 